\title{
Smoking, as a Death Messenger
}

\author{
Hye Jung Park, M.D., Ph.D.
}

Department of Internal Medicine, Gangnam Severance Hospital, Yonsei University College of Medicine, Seoul, Korea

Tobacco smoke is generated by the burning of a complex organic material including tobacco, additives, and paper, at an extremely high temperature. By smoking cigarettes, we can inhale an estimated 7,000 compounds, including numerous toxic components such as benzene, formaldehyde, benzopyrene, carbon monoxide, acrolein, and even metals. These materials cause injury through inflammation, irritation, asphyxiation, carcinogenesis, and other mechanisms ${ }^{1}$. Many studies have revealed that smoking causes various diseases including lung cancer, bronchitis, coronary heart disease, stroke, cataracts, periodontitis, asthma, and hip fractures ${ }^{1}$. Passive (secondhand) smoking is also a risk factor for diseases, including lung cancer, coronary heart disease, and lower respiratory illness ${ }^{2}$. In addition, smoking is deemed the single attributable risk factor for death ${ }^{3,4}$. In this issue, Park et al. ${ }^{5}$ have shown that smoking is a contributable risk for various comorbidities including diabetes mellitus, metabolic syndrome, chronic obstructive pulmonary disease, stroke, angina, and malignancy. They also showed that smoking increased the risk of all-cause-mortality in a dose-response manner, using Korean national data, in this issue. The aforementioned study also showed that the attributable risks (ARs) of smoking for mortality were $21.8 \%$ in males and $9.0 \%$ in females during $2007-2015^{5}$. Evidently, smoking is a death messenger.

Quitting smoking extends smokers' lifespan by 10 years or more and helps them stay healthy ${ }^{6}$. Although many smokers attempt to quit smoking, the quit rate is low $(2 \%-4 \%)$. Many drugs and devices, including varenicline, bupropion, nicotine

\footnotetext{
Address for correspondence: Hye Jung Park, M.D., Ph.D.

Department of Internal Medicine, Gangnam Severance Hospital, Yonsei University College of Medicine, 211 Eonju-ro, Gangnam-gu, Seoul 06273, Korea

Phone: 82-2-2019-3302, Fax: 82-2-3463-3882

E-mail: craft7820@yuhs.ac

Received: Aug. 5, 2020

Revised: Aug. 20, 2020

Accepted: Sep. 8, 2020

Published online: Sep. 8, 2020

(c) It is identical to the Creative Commons Attribution Non-Commercial License (http://creativecommons.org/licenses/by-nc/4.0/).
}

patches, and nicotine gum have been developed to facilitate quitting smoking; however, their success rate is insufficient $(20 \%-40 \%)^{7}$. Anti-smoking policies have been launched worldwide to overcome the limitations of personal strategies. Governments have banned smoking advertisements and increased cigarette taxes. In Korea, the government has established the National Health Promotion Act in 1995, and launched various anti-smoking policies, abolishing military duty-free tobacco in 2009 and mandating the labeling of carcinogens on cigarette cases in 2011. In addition to designating non-smoking areas for public-use facilities in 2012, the government has expanded non-smoking areas, mandated that cigarette cases display warning pictures, and abruptly increased the cigarette tax by $80 \%$ in 2015 (Table 1). Although these national policies showed significant effects in reducing smoking rates ${ }^{8}$, the smoking rate remains high among males in Korea (66.3\% in 1998 and 39.3\% in 2015) ${ }^{9}$. Further smoking cessation strategies at the national level and in clinics should be maintained, improved, and tailored based on individual smokers' circumstances ${ }^{10}$.

In this issue, Park et al. ${ }^{5}$ also showed that ARs of smoking for mortality decreased from $24.2 \%(2007-2010)$ to $19.5 \%$ (2011-2015) in men and from 9.5\% (2007-2010) to $4.1 \%$ (2011-2015) in women. Although they showed no statistically significant difference between the two periods, decreasing trends are evident. The decreasing pattern of ARs of smoking for mortality might be due to governmental anti-smoking policies and the improvement of the smoking rate. Additionally,

Table 1. Anti-smoking policies conducted by the Korean government

\begin{tabular}{|c|c|}
\hline Year & Policy \\
\hline 1995 & $\begin{array}{l}\text { Establishment of the National Health Promotion Act } \\
\text { Launch of anti-smoking policies }\end{array}$ \\
\hline 2005 & $\begin{array}{l}\text { Verification of Framework Convention on Tobacco } \\
\text { Control (FCTC) }\end{array}$ \\
\hline 2009 & Abolition of military duty-free tobacco \\
\hline 2011 & Mandatory labeling of carcinogens on cigarettes cases \\
\hline 2012 & $\begin{array}{l}\text { Designation of "non-smoking areas" for public-use } \\
\text { facilities }\end{array}$ \\
\hline 2015 & $\begin{array}{l}\text { Abrupt increase of tobacco prices (by } 80 \% \text { ) } \\
\text { Mandatory warning picture on cigarettes cases } \\
\text { Expansion of "non-smoking areas" }\end{array}$ \\
\hline
\end{tabular}


medical advances in the treatment of smoking-related diseases might contribute to the reduced mortality. Specifically, molecular targeted therapies and immunotherapies have significantly improved the prognosis of lung cancer ${ }^{11}$, which is largely responsible for smoking-related deaths. Biologics in severe asthma, advanced interventional technologies in coronary artery disease, and new-generation anti-coagulants might also contribute to reducing smoking-related deaths. In addition, other new risk factors for death, including fine dust and e-cigarettes, could contribute to reducing the role played by smoking cigarettes among the attributable risk factors for death.

Smoking tobacco is, evidently, a risk factor for death. Various pharmacotherapies have been developed to assist smoking cessation, and national strategies have been launched to reduce smoking rates. Smoking rates and the attributable rate of smoking for mortality have decreased. However, the smoking rate remains high, and smoking is still a significant attributable factor for death. Further studies concerning smoking are needed.

\section{Conflicts of Interest}

No potential conflict of interest relevant to this article was not reported.

\section{References}

1. Samet JM. Tobacco smoking: the leading cause of preventable disease worldwide. Thorac Surg Clin 2013;23:103-12.

2. Trichopoulos D, Kalandidi A, Sparros L, MacMahon B. Lung cancer and passive smoking. Int J Cancer 1981;27:1-4.
3. Li K, Yao C, Di X, Yang X, Dong L, Xu L, et al. Smoking and risk of all-cause deaths in younger and older adults: a populationbased prospective cohort study among Beijing adults in China. Medicine (Baltimore) 2016;95:e2438.

4. Maag J, Braun J, Bopp M, Faeh D; Swiss National Cohort. Direct estimation of death attributable to smoking in Switzerland based on record linkage of routine and observational data. Nicotine Tob Res 2013;15:1588-97.

5. Park YS, Park S, Lee CH. The attributable risk of smoking on all-cause mortality in Korean: a study using KNHANES IV-VI (2007-2015) with mortality data. Tuberc Respir Dis 2020 Jul 7 [Epub]. https://doi.org/10.4046/trd.2020.0006.

6. Jha P, Ramasundarahettige C, Landsman V, Rostron B, Thun $\mathrm{M}$, Anderson RN, et al. 21st-century hazards of smoking and benefits of cessation in the United States. N Engl J Med 2013;368:341-50.

7. Foulds J, Schmelzer AC, Steinberg MB. Treating tobacco dependence as a chronic illness and a key modifiable predictor of disease. Int J Clin Pract 2010;64:142-6.

8. Kwon DS, Kim TH, Byun MK, Kim HJ, Lee HS, Park HJ, et al. Positive effects of the national cigarette price increase policy on smoking cessation in South Korea. Tuberc Respir Dis 2020;83:71-80.

9. Chamberlain C, O'Mara-Eves A, Porter J, Coleman T, Perlen SM, Thomas J, et al. Psychosocial interventions for supporting women to stop smoking in pregnancy. Cochrane Database Syst Rev 2017;2:CD001055.

10. Chun EM. Smoking cessation strategies targeting specific populations. Tuberc Respir Dis 2019;82:1-5.

11. Kim T, Cha YJ, Chang YS. Correlation of PD-L1 expression tested by 22C3 and SP263 in non-small cell lung cancer and its prognostic effect on EGFR mutation-positive lung adenocarcinoma. Tuberc Respir Dis 2020;83:51-60. 